\title{
EP400 wt Allele
}

National Cancer Institute

\section{Source}

National Cancer Institute. EP400 wt Allele. NCI Thesaurus. Code C118532.

Human EP400 wild-type allele is located in the vicinity of 12 q24.33 and is approximately $131 \mathrm{~kb}$ in length. This allele, which encodes E1A-binding protein p400, is involved in the regulation of both gene expression and histone acetylation. 